\title{
Czech companies will have to deal with import of labour
}

\author{
Eva Kalinová ${ }^{1, *}$, Yaroslava Kostiuk ${ }^{1}$, and Denisa Michutová ${ }^{2}$ \\ ${ }^{1}$ University of Žilina, The Faculty of Operation and Economics of Transport and Communications, \\ Department of Economics, Univerzitná 8215/1, 01026 Žilina, Slovakia \\ ${ }^{2}$ Institute of Technology and Business in České Budějovice, School of Expertness and Valuation, \\ Okružní 517/10, 37001 České Budějovice, Czech Republic
}

\begin{abstract}
Labour market or supply and demand for labour is determined by how individuals demand work (supply) and how the offer of jobs is from the side of companies (demand). This is a very important issue, as it is a part of the main factor markets. The data on labour market are used for analysing the movement of labour market. Thanks to this, it is possible to forecast its approximate development. The basic source are data from the database of the Ministry of Labour and Social Affairs of the Czech Republic. The objective of this paper is to analyse the development of supply and demand for labour in the years 2010-2020 and forecast its development until 2025. The analysis of time series is performed using the method of artificial neural networks, which enables the analysis of the development between 2010 and 2020 and forecasting the further development of supply and demand for labour until the year 2025. The research shows that the development until the year 2025 will not be very favourable. The demand will be much greater than the supply, which means there will be more vacancies than workers. To fill the vacancies and be able to further operate, companies will try to solve this situation by hiring workers from other countries. The results of the paper being submitted may serve for other labour market research.
\end{abstract}

Keywords: labour market, supply and demand for labour, labour market forecasting

\section{Introduction}

The labor market is, like many other markets, made up from supply and demand. Firms through demand for their products and services "derive" demand for work. Households, on the other hand, create labor supply as one of the factors of production. The flexibility of the job offer necessarily depends on the types of job positions. In the short term, it is generally possible to state a lower flexibility of the labor supply, especially for highly qualified job positions due to higher transfers and annuities. It is the transitions between job positions that create frictional unemployment in its natural expression. On the other hand, the highest problem is involuntary unemployment, which occurs most often during cyclical and structural fluctuations.

\footnotetext{
*Corresponding author: kalinova@mail.vstecb.cz
} 
High unemployment rate in many European countries raises concerns of both individuals directly affected by these figures and government and politicians [1], [2].

Labour markets are a good tool to evaluate the performance of the economy, since their observation enables assessing the source of the existing problem, such as unemployment, as well as the success rate of the policies implemented [3].

Svoboda and Applova [4] say, that if jobs offered by various employers are not perfect substitutes, employers have the power to set wages. Its extent can be described by the elasticity of the job supply for the companies [5]. A significant discrepancy between the estimates of the direct elasticity of job offer to changes in wages (lower) and estimates converted from inverted elasticities (higher) indicates that the institutions of labour market can reduce significantly the amount of fixed force determining wages [6]. Tightening of financial conditions leads companies to reduce wages and the number of hours worked per employee [7]. Companies publish fewer vacancies and offer lower wages [8].

A common hypothesis of labour market polarization is that technological progress has reduced the price of machines which are replaceable by medium-skilled jobs and complementary to higher and lower-skilled jobs [9]. Competition between groups of workers and within those groups takes place in the labour markets, which are segmented according to various, often unobservable dimensions [10]. Wage and unemployment rate largely depends on the distribution of unemployment expectations frequency among workers, which is a key feature of the labour market [11].

In macroeconomic literature, most empirical studies that analyse the effects of financial shocks does not address the issues related to labour market [12]. On the one hand, there is an increasing number of theoretical publications analysing the effects of financial shocks on several aspects of the labour market; on the other hand, at the macro level, empirical works include only one variable on the labour market [8].

The objective of the paper is to assess the development of supply and demand for labour in the Czech Republic in the years 2010-2020 and forecast their further development until 2025. In order to achieve the objective, two research questions are formulated:

\section{RQ1: How did supply and demand for labour develop in the years 2010-2020?}

RQ2: What will be the development of supply and demand for labour from 2021 to 2025?

Companies decide on how many and which workers to hire. Nevertheless, in most models of the labour market, all workers have the same probability to be hired. Merkl and Rens [13] argue that selective hiring significantly affects the analysis of welfare. They created a model which is isomorphic to a search model in random hiring but enables selective hiring. In selective hiring, the positive predictions of the model change very little but the consequences for welfare are different for two reasons: first, the hiring externality occurs in random hiring but not in selective hiring. Second, the costs of social security in unemployment are much higher in the case of selective hiring, since the risk of unemployment is unevenly distributed among employees [13].

Fachelli and López-Roldán [14] aimed to confirm the general hypothesis claiming that there is no single labour market that would regulate supply and demand for labour but it can be assumed that several segments will structure hierarchical positions on the labour market in accordance with the specific profiles of job offer. The authors had expected that despite contextual and socio-historical differences they would achieve high correspondence between the individual employment segments.

Rkman [3] specifies a simple search and matching model of the labour market and how well it is able to describe the dynamics of the labour market. The model searches vacancies using two types of shocks: productivity shocks and separation shock. The model estimates the data on unemployment and vacancies using Bayesian methods. The model fits well in the 
data and the estimates show that productivity shocks are the main drivers of fluctuations of the labour market, while separation shocks represent high fluctuating unemployment.

Corbellini, Magnani and Morelli [15] used the method of discriminant analysis and linear or generalized linear models. These models do not consider the presence of possible outliers. At the microeconomic level, theoretical analysis of the functional distribution of income implicitly expressed this assumption by accepting Cobb-Douglas (CD) function for describing production and distribution of income between labour and capital in a sample company. In this context, it holds true that if factor markets are acceptably competitive and the distribution of income reflects the limits of these two factors, the shares of factors are fixed [15].

Nackerdien and $\mathrm{Yu}$ [16] examined the relationships on the labour market between the formal and informal sectors, focusing on three main groups of employees: those who work in the formal sector, those who work in the informal sector, those who worked in both sectors. The authors used econometric analysis, based on which older people and people with higher education are more likely to work in the formal sector.

Benda, Koster and Van Der Veen [17] point to the fact that the dependent variable is measured on a continuous scale; therefore, a suitable analytic method appears to be linear regression. Nevertheless, due to the clustered data structure, where people are clustered into countries, the basic assumption of independent observation is violated, which would result in distortion of the estimates. The common method for analysing clustered data is multilevel modelling (MLM), which considers clustering by means of including random variables.

Molnarova and Rostekova [18] used the methodological model of discourse analysis (DIMEAN). For better understanding of the issue, it was necessary to analyse the sociopolitical development in the last decade with a focus on legislative measures taken in the area of education and to determine the basic theoretical foundations of the research. The research results clearly show that professionalism of secondary education and the need for labour market forecasting are addressed sufficiently [18]. Speckesser, Gonzalez Carreras and Kirchner Sala [19] used aggregate impact analysis to examine the impact of politics on macroeconomic variables, such as employability and youth unemployment. This is based on the assumption that programmes which are efficient in terms of improving individual job opportunities, may affect the balance of youth unemployment. The results show that both wage subsidies and creation of jobs reduce aggregated youth unemployment, which is in the contradiction with the research in several microeconomic studies, which indicate that programmes for creating jobs are not efficient. This points to the importance of helping young people to acquire valuable work experience, which is beneficial for creating jobs, although the work experience is acquired outside regular employment or in the commercial sector [19].

Flek, Hala and Mysikova [20] dealt with the description of the data obtained from the longitudinal database EU-SILC, selected specific countries and a period of the analysis. They explained the concept of the so-called gross flows in the labour market, which can be used to derive the probabilities of the individual transition between employment, unemployment, and economic inactivity. The results focused on the average probabilities of the transition between the situations in the labour markets in individual age groups generally qualitatively coincide with the reference economy of the United Kingdom.

In accordance with the formulated research questions, Flek, Hala and Mysikova [20] document the marginalized status of young people below 24 years in terms of the risk of losing job, which is relatively the highest one of all age groups, followed by unemployment. The so-called "IMF-OECD consensus" indicates that the deregulation of the labour market increases employment and reduces unemployment. Brancaccio, De Cristofaro and Giammetti [21] present a meta-analysis of research on this issue based on the MAER-NET guidelines. The authors analysed the relationship between the indexes of legislation for protecting 
employment on the one hand and employment and unemployment on the other hand. The decrease of support for the consensus view is notable especially in the last decade [21].

\section{Data and methods}

\subsection{Data}

The data on supply and demand on the labour market were obtained from the official website of the Ministry of Labour and Social Affairs [22]. The data are available for the period from 31 January 2010 to 31 December 2020. On their basis, a prediction was made for the period between 31 December 2020 and 31 December 2025.

\subsection{Methods}

Statistical software TIBCO Statistica was used to evaluate the data obtained. The analysis of the time series (regression) is performed using the method of neural networks, where supply and demand for work is a continuous target variable, and date is a continuous predictor. Predictions will be made using three datasets - training, testing, and validation. The training dataset will contain $70 \%$ of the input data, while both testing and validation datasets will contain $15 \%$ of the input data each. Each value will be calculated on the basis of the previous one. There will be used MLP (multilayer perceptron networks). The LP activation functions, which are divided into the neurons in the hidden and output layer, the following functions are used: identity, logistics, atanh (hyperbolic tangent), exponential, and sine.

For the selected type of network (MLP), 2-8 neurons in the hidden layer will be used. The second selected type of network is RBF, for which 17-24 hidden neurons will be used. For the training, 1,000 networks will be generated, out of which 5 will be retained.

Based on the date, the development of the variable will be predicted. The network will be the neural network of the radial basis function. Its performance will be marked by a correlation coefficient, with the ideal value being as close to 1 as possible.

In accordance with the selected methodology, the results will be presented in the following form:

- Analysis of the input data,

- Overview of retained neural networks,

- Graph of supply and demand for labour in the years 2010-2020,

- Graph of predictions.

\section{Results}

Table 1 presents the overall data showing the development of the supply and demand on the labour market in the years 2010-2020. The data were obtained from the website of the Ministry of Labour and Social Affairs [22]. It is a sum of the supply and demand on the last day in December of a given year. This table is compiled only for the comparison of supply and demand in individual years. 
Table 1. Data on supply and demand on the last day of the year

\begin{tabular}{|c|c|c|}
\hline Date & Supply & Demand \\
\hline 31 December 2010 & 561,551 & 30,803 \\
\hline 31 December 2011 & 508,451 & 35,784 \\
\hline 31 December 2012 & 545,311 & 34,893 \\
\hline 31 December 2013 & 596,833 & 35,178 \\
\hline 31 December 2014 & 541,914 & 58,739 \\
\hline 31 December 2015 & 453,118 & 102,545 \\
\hline 31 December 2016 & 381,373 & 132,496 \\
\hline 31 December 2017 & 280,620 & 216,629 \\
\hline 31 December 2018 & 231,534 & 324,410 \\
\hline 31 December 2019 & 215,532 & 340,950 \\
\hline 31 December 2020 & 291,977 & 318,581 \\
\hline
\end{tabular}

Source: Authors.

In accordance with the methodology, 1,000 neural networks (MLP and RBF) were created, out of which 5 with the best values were retained. The results obtained from the three data samples and the aforementioned networks are presented in Table 2. This table shows only the demand for labour. Four out of five retained networks are the MLP networks, one is RBF network. The table also presents correlation coefficient, which is the performance of the network in individual datasets (training, testing, validation), where the values should be as close to 1 as possible. For further analysis, at least one suitable network should be selected. As already mentioned, the closer its value is to 1 , the better; therefore, the model of the network with the highest value is selected most often.

Table 2. Retained neural networks - Demand

\begin{tabular}{|c|l|c|c|c|c|c|c|c|}
\hline Index & Network & $\begin{array}{c}\text { Training } \\
\text { performance }\end{array}$ & $\begin{array}{c}\text { Testing } \\
\text { performance }\end{array}$ & $\begin{array}{c}\text { Validation } \\
\text { performance }\end{array}$ & $\begin{array}{c}\text { Training } \\
\text { error }\end{array}$ & $\begin{array}{c}\text { Testing } \\
\text { error }\end{array}$ & $\begin{array}{c}\text { Validation } \\
\text { error }\end{array}$ & $\begin{array}{c}\text { Training } \\
\text { algorithm }\end{array}$ \\
\hline 1 & MLP 1-7-1 & 0.999110 & 0.997401 & 0.998857 & 12530932 & 11992015 & 20494544 & BFGS 206 \\
\hline 2 & RBF 1-22-1 & 0.997065 & 0.995037 & 0.998912 & 40797090 & 83687524 & 53756542 & RBFT \\
\hline 3 & MLP 1-4-1 & 0.999044 & 0.997411 & 0.998797 & 13427109 & 11368737 & 19782813 & BFGS 309 \\
\hline 4 & MLP 1-7-1 & 0.999176 & 0.997343 & 0.998786 & 11468719 & 13328887 & 21053133 & BFGS 137 \\
\hline 5 & MLP 1-6-1 & 0.999339 & 0.997198 & 0.998969 & 9216361 & 16678819 & 18668172 & BFGS 180 \\
\hline
\end{tabular}

Source: Authors.

All networks show very good performance in all datasets, which is close to the ideal value. However, when summing up the performance in all datasets, it is still possible to determine the most suitable neural structure, 5. MLP 1-6-1. Table 3 below shows 5 retained neural networks from the 1,000 networks generated by the MLP and RBF models. In this case, it is about supply, where the best performance was achieved by the RBF networks. Even in this case, we used training, testing, and validation datasets. 
Table 3. Retained networks - Supply

\begin{tabular}{|c|c|c|c|c|c|c|c|c|}
\hline Index & Network & $\begin{array}{c}\text { Training } \\
\text { performance }\end{array}$ & $\begin{array}{c}\text { Testing } \\
\text { performance }\end{array}$ & $\begin{array}{c}\text { Validation } \\
\text { performance }\end{array}$ & $\begin{array}{c}\text { Training } \\
\text { error }\end{array}$ & $\begin{array}{c}\text { Testing } \\
\text { error }\end{array}$ & $\begin{array}{c}\text { Validation } \\
\text { error }\end{array}$ & $\begin{array}{c}\text { Training } \\
\text { algorithm }\end{array}$ \\
\hline 1 & RBF 1-23-1 & 0.990547 & 0.984797 & 0.985460 & 165727676 & 202189905 & 234466494 & RBFT \\
\hline 2 & RBF 1-24-1 & 0.995834 & 0.991442 & 0.990744 & 75121230 & 93059739 & 156086224 & RBFT \\
\hline 3 & RBF 1-24-1 & 0.989719 & 0.988636 & 0.987465 & 180117147 & 139846032 & 202774460 & RBFT \\
\hline 4 & RBF 1-21-1 & 0.990859 & 0.990833 & 0.987876 & 160238521 & 112071333 & 200791417 & RBFT \\
\hline 5 & RBF 1-22-1 & 0.992161 & 0.982959 & 0.985830 & 137499454 & 258499494 & 229484576 & RBFT \\
\hline
\end{tabular}

Source: Authors.

The values of correlation coefficients are excellent, achieving almost maximum performance. Out of the five retained networks, the best values are achieved by 2.RBF 1-241. Graph 1 shows supply and demand in the years 2010-2020. Each year is represented by the first day in January and July. Supply of labour means that there is an offer from individuals and the number of workers available in the economy. Demand means companies are in demand for labour and want to fill vacancies.

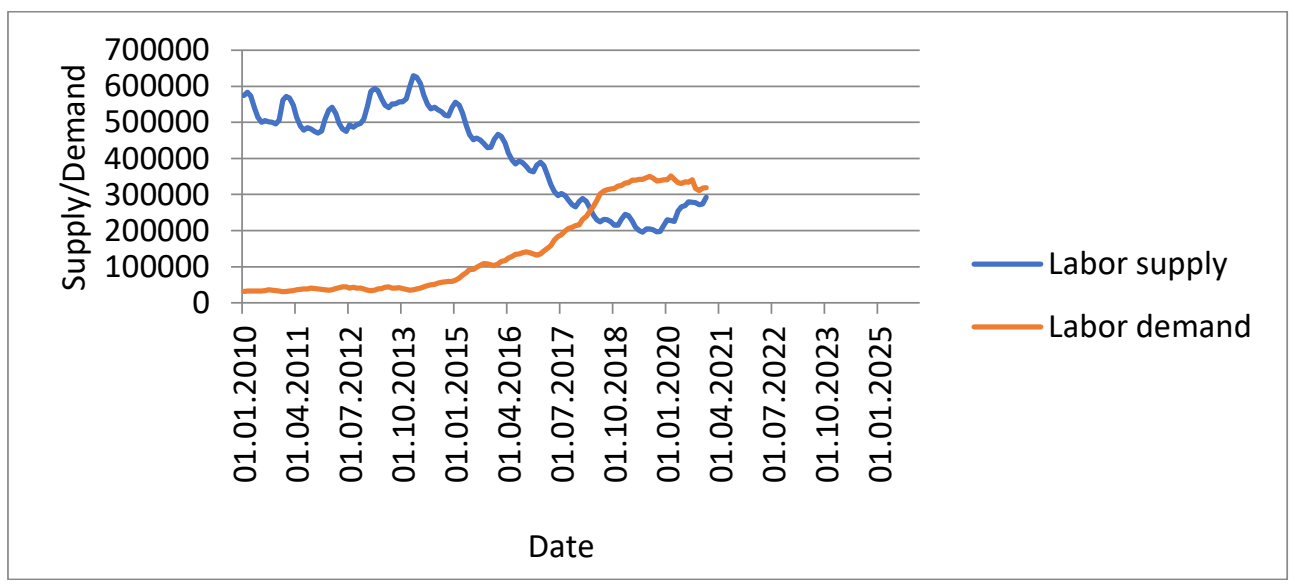

Graph 1. Supply and demand for labour between 2010 and 2020

Source: Authors.

As seen from the graph, supply was very high in the year 2010, achieving almost the value of 580,000; in contrast, at the beginning of 2010, demand was relatively low, not exceeding 32,000. During the decade, approximately at the end of the second half, demand for labour started to grow, exceeding supply in 2018. The peak was achieved in 2014, achieving the value of 630,000. The biggest growth of demand was recorded in 2020, supply and demand started to balance, with the difference between them being nearly 30,000 .

Graph 2 shows supply and demand for labour in the years 2010-2020, which is described in more detail in Graph 1. Graph 2 focuses rather on the prediction made until the year 2025 inclusive. 


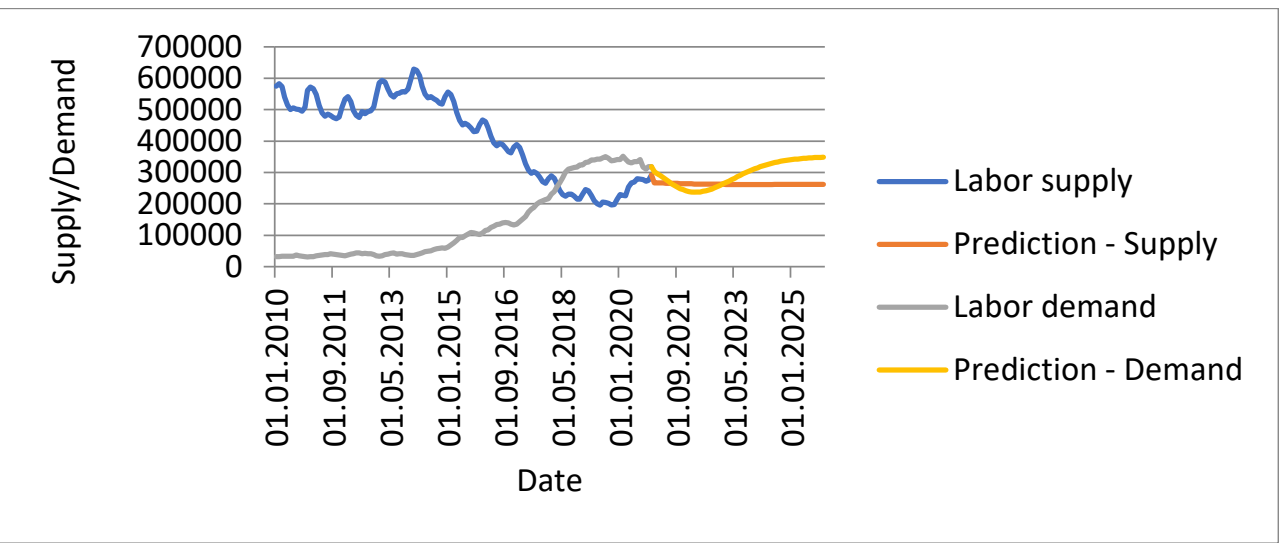

Graph 2. Time series of supply and demand for labour predicted until the year 2025 inclusive Source: Authors.

In 2020, demand starts to balance supply; however, in 2021, the demand begins to decrease from nearly 300,000 almost to 237,000 in 2022; this is also the lowest value in the period between 2020 and 2025. In 2023, demand starts to increase. At the beginning of 2025, the curve stabilizes remains approximately the same for the whole year, with the values fluctuating around 345,000. Supply is at the same level from the beginning of 2021 to 2025 , fluctuating around 260,000.

Graph 3 shows only the prediction for the period 2021-2025, which was described in more detail in Graph 2 above. It is just a more detailed graph of predicted supply and demand for labour in the labour market. The graph presents the data as of the first day in January, April, and July, with the exception of the year 2025, where also October is included.

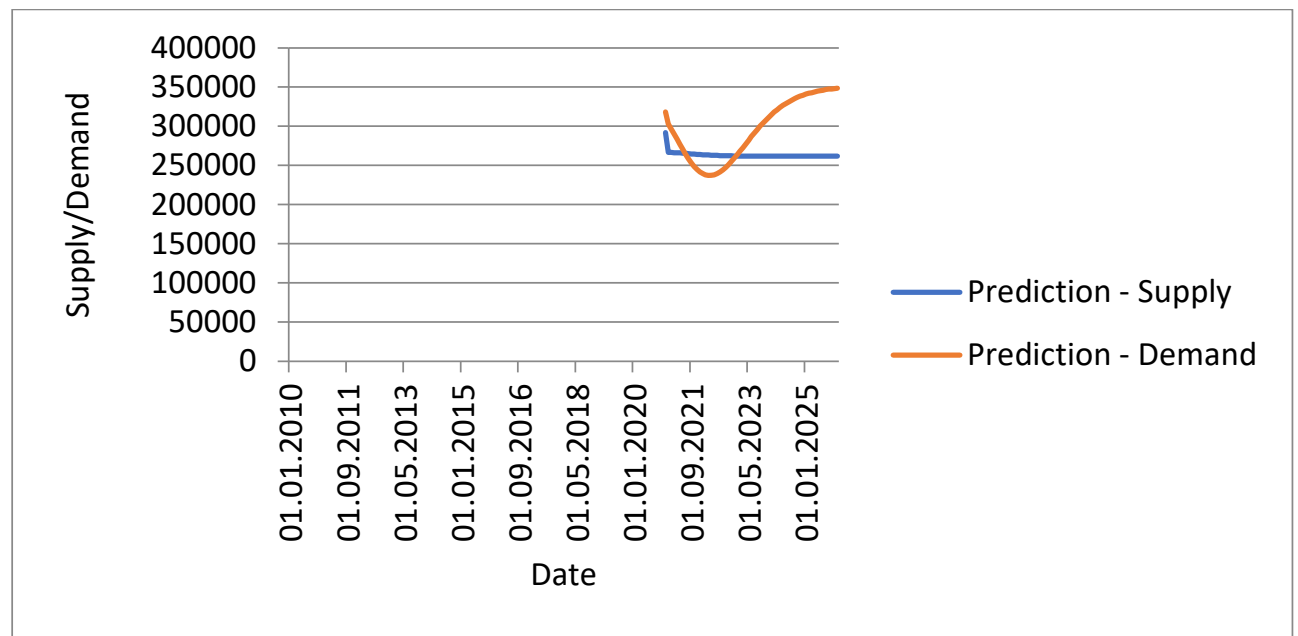

Graph 3. Prediction for the period 2021-2025

Source: Authors.

The predicted supply thus remains approximately at the same level, achieving the values of about 265,000, while demand is predicted to both decrease and increase. At the beginning of 2025, it stabilizes and remains at the same level for the whole year. 


\section{Discussion}

Based on the results obtained, it is possible to answer the research questions formulated in order to achieve the main objective of the paper being submitted:

\section{How did supply and demand for labour develop in the years 2010-2020?}

In the labour market, the decline of supply and the increase in demand for labour slowed down. The effects of the global financial and economic crisis, which started to appear in the labour market at the end of 2008, still continued in 2009. The impacts of crisis were visible even in the first months of the year 2010 [22]. The decline in economic performance from the year 2012 (decrease by $0.9 \%$ ) slowed down slightly in 2013 (decrease by $0.5 \%$ ). In 2014, there was a positive turnaround in the economic development. According to Labour Force Survey (LFS), there was a year-on-year growth (by 1.4\%) in employment in the year 2015 [22]. Along with the growth of the economy, the growth of employment was recorded as well, achieving its peak from the beginning of the economic and financial crisis in 2016. The increase was $1.9 \%$. Despite the positive development of the economy, the lack of suitable labour force became a barrier to more significant growth of employment. The imbalance of employer demand for labour and supply caused a slowdown in employment growth, which fell to $1.6 \%$ in $2017,1.4 \%$ in 2018 , and $0.2 \%$ in 2019 . Currently, the number of registered job seekers is still lower than the number of vacancies announced. In the first quarter of the year 2020, there were 0.7 job seekers per vacancy [22].

The labour market fluctuated between the years 2010 and 2020. In 2010, there was a big difference between supply and demand for labour. At the beginning of 2010, supply fluctuated around the value of 580,000, while demand for labour achieved almost the value of 32,000 . At the end of the decade, the difference between supply and demand was smaller, achieving the value of nearly 30,000 , with demand exceeding supply.

\section{What will be the development of supply and demand for labour from 2021 to 2025?}

Until the year 2025, a slight increase in the number of vacancies is expected in the CR. Compared to the year 2014, the increase accounts for ca. $1.5 \%$, i.e. nearly 80,000 vacancies. However, this does not mean that in the following years, only these new vacancies need to be filled, since this is just the resulting balance between the number of new vacancies on the one side and cancelled jobs on the other side [23].

According to NUV [23], in addition to the independent movement of workers between individual jobs, it will also be necessary to fill the jobs vacated by people leaving the labour market e.g. due to the retirement etc. Moreover, it states that for these reasons, between 2014 and 2025, approx. 1 million of jobs can be vacated in the Czech Republic, which will need to be filled. It is further stated that a lot of jobs will disappear due to the technological progress and ever-increasing efficiency.

By 2025, the fastest decline in the number of employed people is expected in the primary sector. Compared to 2014, in 2025, the number of jobs in this sector will decrease by $6 \%$, i.e. by nearly 17,000 . In the secondary sector, the decrease will be about $2.3 \%$, i.e. 41,000 jobs. Other sectors of the Czech economy are expecting growth in the number of jobs. In the tertiary sector, in 2025, it shall be an increase by 14,000 (about $1 \%$ ) compared to the year 2014. In public quaternary sector, the increase is nearly $36,000(3.5 \%)$, while in quaternary business sector, it will be more than 83,000, which accounts for $10 \%$ [23]. At the beginning of the year 2021, supply fluctuates at the same level around the value of 266,000. Demand will fluctuate more and starts to decrease at the beginning of the year 2021. The year 2022 will show a continuous decrease in demand, but at the turn of 2022/2023, demand will 
increase, exceeding supply. At the end of the year 2025, its value will achieve approx. 348,000 .

\section{Conclusion}

The objective of the paper was to assess the development of supply and demand for labour in the Czech Republic in the years 2010-2020 and to predict their further development until the year 2025. Using time series, the method of artificial neural networks, it was possible to identify the development of supply and demand for labour in specific years and to predict its further development. The objective of the paper was thus achieved.

In the years 2010-2020, supply and demand fluctuated. Due to the economic crisis in 2008 , demand for labour was lower than supply at the beginning of the year 2010, with demand achieving the value of approx. 33,000 and supply approx. 580,000. Demand and supply were thus unbalanced until 2018, when demand for labour balanced and even exceeded supply until the end of the year 2020.

As for the predicted supply and demand for labour, supply is expected to remain at the same level until the end of the year, while demand will fluctuate slightly. A decrease is expected at the beginning of the year 2021, which will be followed by an increase with expected stabilization until the year 2025 .

This means that the number of vacancies will exceed the number of workers; any individual interested in finding a job will be able to find it without any problems. In contrast, some companies will lack employees. If they are not able to find enough employees soon, it will result in the reduction of production and this would mean bankruptcy. For the state, the fact that companies will not make profit and will not be able to pay taxes, it would mean loss of financial resources used to finance social care, pensions, and other social benefits.

To improve the situation, I would recommend companies to hire labour from other states so that they are able to fill the vacancies and are able to operate. This would also enable people from economically less developed countries to get a job and higher salary. Companies would fill the vacancies, which would enable them to continue operating and the state would thus have sufficient financial resources for the state budget.

On the other hand, it is appropriate to look at the results from a qualitative view. Although the epidemic increase in jobs is evident, it seems that the national economy is generating one that, in essence, is of little interest. They can be defined as supporting activities within production processes and especially also craft activities. The element of manualness is therefore highly undesirable on the labor market in the Czech Republic.

The ongoing migration in the labor market, which is currently somewhat limited by the situation around COVID-19, is a completely natural economic phenomenon. However, there is still a large social group of the economically productive population that perceives migration as a threat to their job certainty. After all, many political actors are aware of this fact. The result is the determination of appropriate party and election programs aimed at obtaining political rents.

Based on the above results and given the current situation concerning COVID-19, the following questions may arise: How will the labour market, or more specifically supply and demand for labour develop after this turnover? Will the Czech Republic be able to recover as soon as possible? Will it be visible in the following years that the world was affected by this disease, due to which many people have lost or will lose their jobs? To answer these questions, further research shall be conducted. 


\section{References}

1. D. Stroukal, The short-term relationship between unemployment and home ownership. Littera Scripta, 9(1), 140-153 (2016)

2. S. Haskova, P. Volf, V. Machova, Economic convergence of Czech regions in terms of GDP and unemployment rate in response to FDI flows: Do businesses and regions flourish? Ad Alta: Journal of Interdisciplinary Research, 9(1), 326-329 (2019)

3. J. Rkman, An estimated search and matching model of the Croatian labor market: Postcrisis analysis. Croatian Economic Survey, 22(2), 35-72 (2020)

4. O. Svoboda, P. Applova, Determinants of employment and GDP resilience in the context of an economic crisis: Evidence from EU countries and regions. Littera Scripta, 9(2), 140-155 (2016)

5. V. Novak, M. Vokoun, F. Stellner, M. Vochozka, Institutional analysis of the contemporary regional labour market in the Czech Republic. E+M Ekonomie a Management, 19(3), 4-15 (2016)

6. A. Sokolova, T. Sorensen, Monopsony in labor markets: A meta-analysis. ILR Review, 74(1), 27-55 (2021)

7. J. Deggans, T. Krulicky, M. Kovacova, K. Valaskova, M. Poliak, Cognitively enhanced products, output growth, and labor market changes: Will artificial intelligence replace workers by automating their jobs? Economics, Management, and Financial Markets, 14(1), 38-43 (2019)

8. F. Corsello, E. Valerio Nispi Landi, Labor market and financial shocks: A time-varying analysis. Journal of Money, Credit and Banking, 52(4), 777-801 (2020)

9. Ch. Vom Lehn, Labor market polarization, the decline of routine work, and technological change: A quantitative analysis. Journal of Monetary Economics, 110, $62-$ 80 (2020)

10. N. M. Wiener, Labor market segmentation and immigrant competition: A quantal response statistical equilibrium analysis. Entropy, 22(7), (2020)

11. J. J. Silveira, G. T. Lima, Can workers' increased pessimism about the labor market conditions raise unemployment? International Review of Economics \& Finance, 72, $125-134$ (2021)

12. I. Kmecova, J. Stuchly, L. Polanecky, M. Suta, Analysing structure of employed and unemployed population of Czech Republic as part of human capital on labour market. Littera Scripta, 12(1), 121-141 (2019)

13. Ch. Merkl, T. Van Rens, Selective hiring and welfare analysis in labor market models. Labour Economics, 57, 117-130 (2019)

14. S. Fachelli, P. López-Roldán, Comparative Perspectives on Social Indicators. Social Indicators Research: An International and Interdisciplinary Journal for Quality-of-Life Measurement, 154(3), 755-765 (2021)

15. A. Corbellini, M. Magnani, G. Morelli, Labor market analysis through transformations and robust multivariate models. Socio-Economic Planning Sciences, 73 (2021)

16. F. Nackerdien, D. Yu, A panel data analysis of the formal-informal sector labour market linkages in South Africa. Development Southern Africa, 36(3), 329-350 (2018)

17. L. Benda, F. Koster, and R. Van Der Veen, Active labour market policy as a socialising agent: a cross-national analysis of learning attitudes. Studies in Continuing Education, 42(1), 75-101 (2020) 
18. E. Molnarova, M. Rostekova, Educational policy of the Slovak Republic in the context of changes in the labour market: Media discourse analysis. Politické Vědy, 23(4), 47-64 (2020)

19. S. S. Speckesser, F. J. Gonzalez Carreras, L. Kirchner Sala, Active labour market policies for young people and youth unemployment. International Journal of Manpower, 40(8), 1510-1534 (2019)

20. V. Flek, M. Hála, M. Mysíková, Unemployment and age-based labor market segmentation. Politická Ekonomie, 66(6), 709-731 (2018)

21. E. Brancaccio, F. De Cristofaro, R. Giammetti, A meta-analysis on labour market deregulation and employment performance: No consensus around the IMF-OECD consensus. Review of Political Economy, 32(1), 1-21 (2020)

22. MLSA, Ministerstvo práce a sociálních věcí [Ministry of labour and social affairs] [online], Available at: https://www.MLSA.cz (2021)

23. NUV, Národní ústav pro vzdělání [National institute of education] [online], Available at: http://www.nuv.cz (2021) 